\title{
Microcomputer Calculation of Growth Regulator Solutions
}

\section{David A. Gilbertz \\ Department of Horticulture, University of Georgia, Georgia Station, Griffin, GA 30223}

Additional index words. computer program, soil drench, spray

The chemical concentration used during application of plant growth regulators is important for obtaining a desirable response (Davis et al., 1988; Larson, 1985). Even small errors in calculating growth retardant dilutions can delay flowering, reduce flower size, or cause excessive or inadequate height control. Some articles elucidate the formulae and calculations for soil drenches and sprays used with ornamental crops (Barrett, 1983; Gilbertz, 1989), but a computer program would simplify the calculations even further. With this in mind, a stand-alone microcomputer program was written (Fig. 1) that simplifies the calculations involved and provides information on costs per application.

The software is written in BASIC and compiled as a stand-alone executable program for IBM-compatible computers (minimum configuration: $64 \mathrm{~K}$ and one floppy drive). The program presents a menu of growth retardants stored in a separate data file. Other compounds can be added permanently to the menu by answering a series of program prompts. The user can choose to input cost of the compounds, which will be used to calculate the expense of the requested treatment and number of plants treatable for the container size and chemical concentra-

Received for publication 16 May 1991. Accepted for publication 12 Nov. 1991. The cost of publishing this paper was defrayed in part by the payment of page charges. Under postal regulations, this paper therefore must be hereby marked $a d$ vertisement solely to indicate this fact. tion specified. These results may be useful for economic comparison of compounds or to answer "what if" questions. Calculations can be based on final solution quantity needed, bench area to be sprayed (calculated at 200 $\mathrm{ml}$ solution $/ \mathrm{m}^{2}$ ), or number of plants to be drenched. Chemical sprays are calculated using milligrams per liter or percent solution. Soil drenches are determined using desired drench volume and rate expressed as milligrams per plant, grams per plant, or milligrams per liter. Solutions are then calculated and mixing instructions are displayed on screen in metric and English units. The dilution/cost screen changes depending on the treatment quantity (Fig. 2).

Scientists can obtain a free copy of the program (additional significant digits were added for scientific use) by sending a selfaddressed diskette mailer with formatted diskette to D.A.G. Commercial operators can obtain a copy with users' guide for nominal

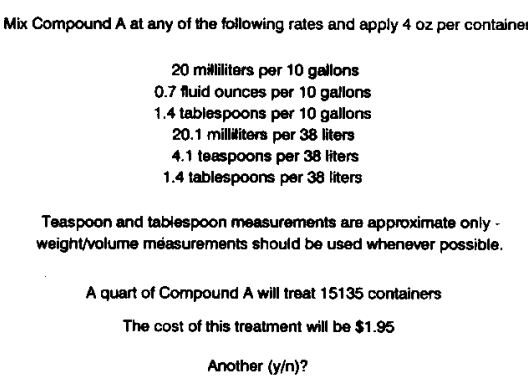

Fig. 2. Mixing instructions for 10 gallons (37.9 liters) of solution to apply $0.25 \mathrm{mg}$ of compound A per container as a 4-fl. oz (118.3-ml) soil drench $(y / n=y e s / n o)$.

charge through: UGA Extension Service, Management Operations, 215 Conner Hall, Athens, GA 30602, 404/542-8999.

\section{Literature Cited}

Barrett, J.E. 1983. Calculating dilutions for ARest, B-Nine and Cycocel. Florists' Rev. 173:31-34.

Davis, T.D., G.L. Steffens, and N. Sankhla. 1988. Triazole plant growth regulators, p. 63-105. In: J. Janick (ed.). Hort. Rev., vol. 10. Timber Press, Portland, Ore.

Gilbertz, D.A. 1990. Growth retardant mixing made easy. Greenhouse Grower 8:66-69.

Larson, R.A. 1985. Growth regulators in floriculture, p. 399-481. In: J. Janick (ed.). Hort. Rev., vol. 7. AVI, Westport, Conn.

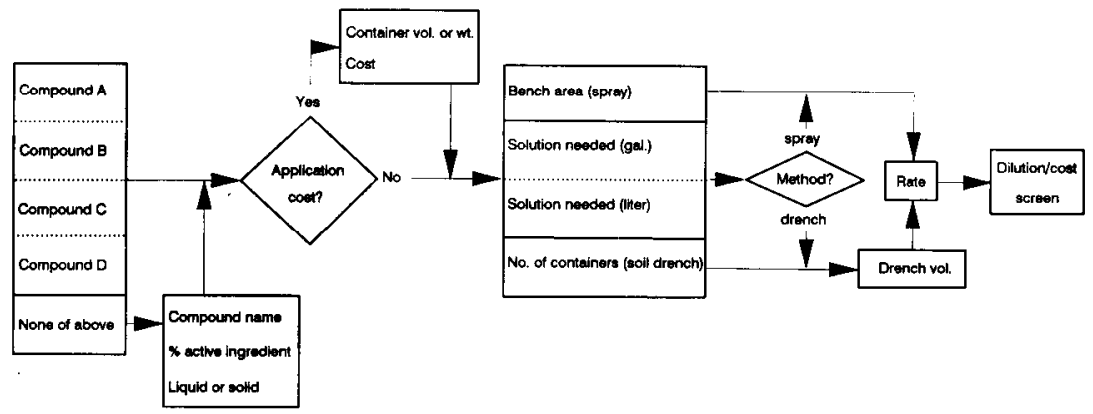

Fig. 1. Flow chart of program to calculate growth regulator solutions. 